\title{
Celovit in enovit sistem predšolske vzgoje z integracijo vzgojno-izobraževalne, zdravstvene in socialne dimenzije
}

\author{
Sonja Rutar \\ Univerza na Primorskem \\ sonja.rutar@pef.upr.si
}

\begin{abstract}
Sistem in organiziranost predšolske vzgoje v slovenskih vrtcih je celovit in enovit - zagotavlja povezanost skrbi/varstva, vzgoje in izobraževanja v prvem in drugem starostnem obdobju. Med prvim in drugim starostnim obdobjem so zagotovljene razvojna, pedagoška in profesionalna kontinuiteta. Sedanja oblika enovitega sistema in kontinuitete je bila zagotovljena že z Vzgojnim programom za vzgojo in varstvo predšolskih otrok (1979), nadaljevala se je s Kurikulumom za vrtce (Ministrstvo za šolstvo in šport, 1999). Problem, ki ga želimo v prispevku nasloviti, je, kako zagotoviti, da bodo vrtci ohranili senzibilnost in integriran pristop do otrok in njihovih družin z vključevanjem vzgojnoizobraževalne, zdravstvene in socialne dimenzije, ob zavedanju, da so otrokovi razvojni potenciali, zmožnosti za razvoj in učenje ter zdravje v neposredni povezavi s socialno-ekonomskimi pogoji otrok in njihovih družin.
\end{abstract}

Ključne besede: predšolski otrok, družina, kurikulum, učenje, razvoj

\section{Uvod}

V organizirano predšolsko vzgojo v Sloveniji so v skladu z Zakonom o vrtcih (2005) vključeni otroci od enajstega meseca starosti do vstopa v šolo. Kljub formalni delitvi skupin otrok na prvo in drugo starostno obdobje so vrtci organizirani enovito in celovito, $z$ namenom zagotavljanja varstva in vzgoje $v$ izobraževalnem sistemu, kar ni značilno za vse države evropskega prostora.

Skupno stališče na ravni OECD je, da sta skrb/varovanje in izobraževanje koncepta, ki sta v kakovostnih vrtcih medsebojno povezana (OECD 2001, 14; 2006). Slovenija ima konceptualno prednost pri organizaciji vzgoje, saj epistemološko vzgoja v najširšem pomenu vključuje (1) vzgojo, ki predstavlja seznanjanje $z$ vrednotami, razvoj skrbi posameznika zase in za druge in razvoj odnosov z drugimi, ter (2) izobraževanje, ki vključuje pridobivanje znanj, spretnosti in $s$ tem tudi razvoj sposobnosti. Obenem pa je organizirana predšolska vzgoja že v času Pestalozzija (1746-1827) poleg učenja, pridobivanja spoznanj skozi najrazličnejše aktivnosti, vključevala tudi nego in skrb za otroke ter njihovo zdravje (Žlebnik 1978), kar je za predšolsko vzgojo 
značilno tudi v sodobnem času (Marjanovič Umek, Fekonja Peklaj, Hočevar in Lepičnik Vodopivec 2011). Predvidevamo, da bi morebiten prehod z integrirane vzgojno-izobraževalne, socialne in zdravstvene skrbi za otroke ter njihove družine ( $v$ okviru organizirane predšolske vzgoje) na izključno vzgojno-izobraževalno predstavljal izključevanje dimenzij, ki so medsebojno povezane, soodvisne in pri vzgoji, izobraževanju in skrbi za najmlajše otroke vedno prisotne. Zato verjamemo, da je mogoče zagotavljati ustrezno vzgojo in izobraževanje za otroke v njihovem najzgodnejšem obdobju zgolj z interdisciplinarno povezanostjo zdravstvenih, medicinskih, pedagoških, psiholoških, socialnih in kulturno informiranih spoznanj.

V prispevku izpostavljamo pomen (1) celovitega in enovitega sistema predšolske vzgoje $v$ pristojnosti resornega ministrstva za izobraževanje, $z$ integracijo (2) vzgojno-izobraževalnega, zdravstvenega in socialnega področja ter z zagotovljeno (3) profesionalno, pedagoško in razvojno kontinuiteto v pedagoških pristopih.

\section{Celovit in enovit sistem predšolske vzgoje v pristojnosti resornega ministrstva za izobraževanje}

Vpogled v organiziranost predšolske vzgoje v različnih državah kaže (Eurydice 2019), da je Slovenija ena izmed redkih držav, ki (1) celovito povezuje skrb, varstvo in izobraževanje ter (2) zagotavlja enovito organizacijo in financiranje vzgoje za otroke prvega ter drugega starostnega obdobja. V državah, $v$ katerih je skrb za otroke $v$ najzgodnejšem obdobju (do tretjega leta starosti) v pristojnosti socialnega varstva, za starejše otroke pa v pristojnosti resornega ministrstva za izobraževanje, sta dve starostni obdobji z vsebinskega in organizacijskega vidika ter načina financiranja ločeni, kar predstavlja težavo pri zagotavljanju celovitega in integriranega sistema vzgoje s povezanostjo zdravstvene, socialne in vzgojno-izobraževalne dimenzije. Enovit sistem vzgoje in izobraževanja je organiziran samo na Hrvaškem, v Latviji, Litvi, na Finskem, Švedskem, v Bosni in Hercegovini, na Islandiji, v Črni Gori, Severni Makedoniji, na Norveškem, v Srbiji in Sloveniji (Eurydice 2019). Posledično imajo programe in smernice za pedagoško delo zgolj z otroki drugega starostnega obdobja v Belgiji (flamska skupnost), Bolgariji, na Češkem, v Italiji, Franciji, Cipru, Luksemburgu, Avstriji, na Poljskem, Portugalskem, Slovaškem, v Lihtenštajnu in Švici (Eurydice in Eurostat 2014). V navedenih državah za skupine mlajših otrok ni predpisanega pedagoškega programa, kar kaže na diskurz, ki ob odsotnosti pedagoških vodil oziroma načel lahko vodi v manj strukturirane in načrtovane vzgojno-izobraževalne spodbude ter ravnanja v času otrokovega bivanja v vrtcih. 
Prvotna skrb, vzgoja in zaščita otrok v času odsotnosti staršev, je bila s prisotnostjo pedagoškega diskurza (ki verjame $v$ otrokove spoznavne zmožnosti in omogoča razvoj z zagotavljanjem pogojev za učenje) $z$ izobraževalnimi elementi (cilji in nalogami) $v$ Sloveniji prisotna že $z$ državnim načrtnim ustanavljanjem otroških vrtcev, osnovnošolskim zakonom, sprejetim 14. maja 1869. Povezanost igre in poučevanja v ciljih in dejavnostih je prisotna, skladno s Fröeblovim konceptom, že v učnih načrtih za vrtce, ki so ga pripravile uršulinke leta 1908 (Pavlič 2006).

Skrb, varstvo ter vzgoja in izobraževanje so bili povezani v celovito dejavnost tudi v prvem nacionalnem programu za vrtce, Vzgojnem programu za vzgojo in varstvo otrok, nastalem leta 1979. $V$ tem dokumentu so bili opredeljeni vsebine in program vzgojnega dela za otroke do tretjega leta starosti ter vzgojni program za otroke od tretjega leta do vstopa $v$ šolo. Vzgojni program za vzgojo in varstvo predšolskih otrok je določal, da se v vzgojnovarstveni zavod vključujejo otroci, stari od 8 mesecev do 7 let, in prebijejo v njem tudi do 10 ur dnevno (Vzgojni program za vzgojo in varstvo otrok 1979, 6). Že $v$ tem dokumentu je bilo poudarjeno preseganje izključno varstvene vloge vrtca v času materine odsotnosti otrok. Program je izhajal iz spoznanj o velikih spoznavnih zmožnostih otrok, poudarjal je vlogo vrtca oziroma ustrezne predšolske vzgoje za razvoj otrokovih dispozicij, sposobnosti ter vpliv socialnega, družinskega in družbenega okolja na razvoj otrok. Poudarjeni sta bili tudi nega in skrb za zdravje otrok. Od vzgojitelja se je pričakovalo, da sledi spoznanjem s področja psihologije, mentalne higiene, medicine in pedagogike. Zato je bila vzgojno-varstvena dejavnost pojmovana kot pomoč družini in dopolnitev vzgoje ter nadomestilo v času, ko sta bila starša zaposlena (Vzgojni program za vzgojo in varstvo otrok 1979). Tako današnja organiziranost predšolske vzgoje v Sloveniji izhaja iz tradicionalnega in načrtnega vertikalnega organiziranja ter povezovanja skupin otrok prvega in drugega starostnega obdobja.

Organizirana predšolska vzgoja v vrtcih je bila v Sloveniji po osamosvojitvi najprej v pristojnosti Republiškega komiteja za zdravstveno in socialno varstvo, od leta 1993 pa resornega ministrstva za izobraževanje. V Kurikulumu za vrtce (Ministrstvo za šolstvo in šport 1999), zdravstveni in socialni vidik nista eksplicitno izpostavljena, vendar je bilo v Zakonu o vrtcih leta 1996 opredeljeno, da so temeljne naloge vrtcev pomoč staršem pri celoviti skrbi za otroke, izboljšanje kvalitete življenja družin in otrok ter ustvarjanje pogojev za razvoj otrokovih telesnih in duševnih sposobnosti.

Utemeljen prenos organizirane predšolske vzgoje v pristojnost resornega ministrstva za izobraževanje je povezan predvsem s spoznanji o velikih raz- 
vojnih potencialih otrok, ključni vlogi najzgodnejših izkušenj v aktualnem in kasnejšem razvoju otrok (Phillips in Shonkoff 2000) ter vplivu vrste in kakovosti izkušenj, ki jim je otrok izpostavljen v različnih družinskih okoljih, na otrokov razvoj in učenje (Hart in Risley 1995).

Način organizacije in vsebinski vidik skrbi za predšolske otroke pa sta vedno manifestacija podobe o otroku (Malaguzzi 1994), razumevanj in interpretacije otrokovih potencialov, prepričanj in razlag vlog, ki jih ima otrok v družbi. Phillips in Shonkoff $(2000,2)$ sta v odmevni raziskavi skupaj s sodelavci povzela dotedanja spoznanja o razvoju in učenju otrok. Poudarjata:

- pomen zgodnjih izkušenj v življenju otrok ter centralno nalogo in vlogo zgodnjih odnosov z otroki kot virom pomoči, podpore v situacijah, ko otrok potrebuje podporo;

- vpliv interaktivnega delovanja genetskih in okoljskih vplivov na razvoj možganov in način otrokovega delovanja;

- velike razvojne zmožnosti otrok;

- zmožnost razvoja kompleksnega čustvovanja v zgodnjem otroštvu, kar predstavlja zmožnost za razvoj ključnih socialnih spretnosti v prvih letih otrokovega življenja;

- obstoj kapacitet za spreminjanje poti otrokovega razvoja skozi načrtovane aktivnosti.

Spoznanja implicirajo, da za otroka v najzgodnejšem obdobju ni dovolj zgolj skrb, ki se manifestira v oskrbi in varovanju, pač pa je pomembno zagotavljanje ustreznih, načrtovanih izkušenj, ki pomembno vplivajo na otrokovo učenje in razvoj, še posebno na učenje in razvoj otrok, ki prihajajo iz depriviligiranih okolij (Burger 2010).

Ob dejstvu, da obstajajo različne oblike organizirane predšolske vzgoje v mednarodnem okolju, Peter Moss in John Bennett (2006) poudarjata, da je v vseh državah potrebno zagotoviti integriran sistem varstva in izobraževanja. Za to, da bi države lahko zagotovile integriran sistem, menita, da je potrebno zadostiti naslednjim pogojem:

- Razširiti je potrebno vrednote in načela javnega izobraževalnega sistema na vse predšolske inštitucije/vrtce z zagotavljanjem dostopa do visokokakovostnih vrtcev za vse otroke, kar velja za univerzalno pravico; postati mora brezplačna ali javno subvencionirana storitev, ki se priznava kot javno dobro, financirano s strani države, in ne kot zasebna dejavnost, kot je organizirana v nekaterih državah. 
- Organizirati je potrebno enoten strukturni okvir, ki bo nadomestil paralelno strukturo, ločeno na varstvo in izobraževanje. To je mogoče zagotoviti z ustreznim financiranjem in novim poklicem predšolskega učitelja/vzgojitelja, ki dela z otroki do tretjega leta starosti in po tretjemu letu starosti.

- Razviti je potrebno integrativni koncept, ki zajema učenje, skrb in psihološko blagostanje najmlajših otrok, kar presega politiko in prakso "zgodnjega izobraževanja« in »varstva otrok« kot ločenih subjektov.

Kasneje so Kaga, Bennett in Moss (2010) preučevali situacijo ločenih in celovitih integriranih sistemov $v$ različnih državah. Ugotavljajo, da ni mogoče govoriti o absolutni prednosti integriranega sistema, če se integracija ne zgodi postopno in premišljeno, $z$ jasno konceptualizacijo namena sprememb. Sprememba z umeščenostjo predšolske vzgoje na področje izobraževanja ne zahteva zgolj formalnih sprememb na ravni prenosa pristojnosti na področje izobraževanja, pač pa soočanje z nevarnostmi »pošolanja« vrtcev, možnosti poslabšanja odnosov, nepovezanosti z drugimi področji (zdravje, sociala) in povečanja stroškov $z$ boljšo izobrazbeno strukturo zaposlenih in $s$ pripravo novega kurikuluma. Mednarodna spoznanja tako omogočajo refleksijo obstoječe strukture slovenske predšolske vzgoje in podobe o otroku. $\checkmark$ Sloveniji ima sedanja ureditev in organizacija vrtcev naslednje značilnosti:

- zagotovljen je organizacijsko enovit (organizacijsko povezana vzgoja in izobraževanje prvega in drugega starostnega obdobja) ter celovit (povezanost skrbi/varovanja, vzgoje in izobraževanja) sistem vzgoje in izobraževanja;

- strokovni delavci, zaposleni v vrtcih, so izobraženi za delo v prvem in drugem starostnem obdobju;

- kurikulum vsebuje cilje in dejavnosti za delo z otroki obeh starostnih obdobij;

- obstaja pa nevarnost nepovezanosti, neintegriranosti z drugimi področji - zdravstvom in socialnim varstvom.

Stanje v slovenskih vrtcih kaže na upoštevanje velikih razvojnih potencialov otrok, njihovih zmožnosti za učenje, kar se odraža pri vzpostavljanju profesionalne in pedagoške kontinuitete. Ob poudarjanju izobraževalne vloge predšolske vzgoje, pomembne predvsem za otroke, ki imajo manjše priložnosti za pridobivanje akademskih znanj in spretnosti v domačih okoljih, pa 
je potrebno upoštevati, da je otrok vpet v različna socialno-ekonomska okolja, ki pomembno vplivajo na njegove (z)možnosti za učenje in zdravje.

\section{Povezanost vzgojno-izobraževalnega, socialnega in zdravstvenega področja}

»Vsak otrok ima pravico do enakih možnosti za razvoj« je najpogostejši slogan vlad, ki v svojih odločitvah upoštevajo spoznanja o vplivih okolja na otrokov razvoj. Okolje in strukturni družbeni pogoji zato vplivajo tudi na (z)možnosti otrokovih družin za zagotavljanje optimalnega razvoja otrok. Ta spoznanja vlade vodijo k prizadevanjem za organizacijo dostopa do visokokakovostnih vrtcev za vse otroke. Študije namreč kažejo, da zgodnje intervencije in predvsem visokokakovostni predšolski programi vplivajo na otrokove kasnejše učne dosežke ter življenjske navade, odnose z drugimi, zdravstveno in socialno-ekonomsko stanje $v$ odrasli dobi (Vandenbroeck 2011; Woodhead, Grantham-McGregor in Klaus 2015).

Čeprav so sistematični zbrani dokazi o vplivih okolja na otrokovo učenje in razvoj na voljo šele v sodobnem času (Hart in Risley 1995), so vrtci od samega nastanka (Žlebnik 1978) povezovali vzgojno-izobraževalno, socialno in zdravstveno področje. Podobno je usposabljanje negovalk (1840) in kasneje vzgojiteljic (1950) vključevalo vsebine o higienskih pravilih. Kasneje, v drugi polovici 20. stoletja, so bile te vsebine zajete v zdravstveni vzgoji (Lepičnik Vodopivec in Hmelak 2018).

$\mathrm{V}$ normative in strukturne standarde slovenskih vrtcev je tudi danes zajet zdravstveni vidik; določeni so tehnični in zdravstveno higienski normativi, nadzorovana priprava prehrane, organizirani obiski zobozdravstvenih delavcev $v$ vrtcih in organizirana predavanja pediatrov za starše otrok. Pomembnost zdravja in sistemske skrbi za zdravje poudarja tudi M. RossinSlater (2015), ki je ugotovila, da so odrasli bolj zdravi, višje izobraženi in živijo tudi v boljših ekonomskih razmerah, če so bili zdravi v zgodnjem otroštvu. Vendar je $v$ svoji raziskavi ugotovila tudi, da je zdravje otrok $v$ neposredni povezavi s socialnimi razmerami, v katerih živijo otroci v družinskem okolju.

Socialno vlogo vrtcev in s tem upoštevanje družinskih/socialnih razmer opredeljuje 20. člen Zakona o vrtcih, ki določa, da ima v skladu z odločbo pristojnega organa pri sprejemu $v$ vrtec prednost otrok $s$ posebnimi potrebami. Prednost pri sprejemu v vrtec ima tudi otrok, za katerega starši predložijo mnenje centra za socialno delo o ogroženosti zaradi socialnega položaja družine. Mnenje o ogroženosti otroka zaradi socialnega položaja družine vsebuje navedbe, da je družina v skladu s predpisi, ki urejajo socialno varnost oziroma položaj družine, obravnavana kot socialno ogrožena družina s 
strani centra za socialno delo, kar je razvidno iz uradnih evidenc, ki jih vodijo centri za socialno delo. Ustanovitelj pa določa tudi druge kriterije pri vključevanju otrok v vrtec, če število prijavljenih otrok presega razpoložljivo število mest. Ti pogosto vključujejo število otrok v družini ter posebno skrb za enostarševske družine in družine, v katerih sta zaposlena oba starša oziroma sta starša študenta. Upoštevajo se tudi priporočila razvojne ambulante, dispanzerja za psihohigieno ali svetovalnega centra z navedbo razlogov za nujnost vključitve otroka v vrtec (Pravilnik o sprejemu otrok v vrtec 2012).

Poudarjeno vlogo vrtcev pri zagotavljanju ustreznih pogojev za otrokov razvoj v družinskih okoljih je mogoče prepoznati tudi v smernicah za svetovalno delo v vrtcih (Čačinovič 2008). Področja delovanja svetovalne službe v vrtcih so: (a) svetovalno delo z otroki, (b) svetovalno delo z vzgojitelji in pomočniki vzgojiteljev, (c) svetovalno delo s starši in družinami, (č) sodelovanje $z$ vodstvom vrtca, (d) sodelovanje z zunanjimi ustanovami. Pri svetovalnem delu s starši se od svetovalne službe pričakuje zagotavljanje pomoči staršem pri njihovem vključevanju v vzgojno-izobraževalno delo v oddelku, zagotavljanje pomoči staršem pri razumevanju in spodbujanju otrokovega razvoja ter učenja v predšolskem obdobju in pri opravljanju starševske vloge ter pomoč staršem, ko je zaradi njihovih različnih osebnostnih, socialnih, zdravstvenih ali materialno-ekonomskih stisk ogrožen otrokov normalni razvoj (Čačinovič 2008, 20).

Kljub dobro organizirani mreži javnih vrtcev M. Šebart Kovač in Štefanc $(2017,125)$ v slovenski študiji o položaju otrok v Sloveniji danes ugotavljata, da je treba povečati delež vključenosti otrok $v$ vrtce $v$ Sloveniji, predvsem v prvem starostnem obdobju, in zagotoviti sistemske ukrepe, ki »spodbujajo vključevanje otrok v vrtce, še posebno tiste, ki prihajajo iz manj spodbudnega okolja, robnih skupin, priseljencev in otrok s posebnimi potrebami«.

Ob spoznanjih, da ima organizirana predšolska vzgoja pozitiven vpliv na otrokov razvoj, še posebno otrok, ki prihajajo iz depriviligiranih okolij, Vandenbroeck (2011) opozarja, da izobraževalni sistem pogosto reproducira socialno neenakost z zanikanjem situacij in potreb staršev ter pogosto prezrtostjo stanj, s katerimi se soočajo starši in otroci iz depriviligiranih okolij. Sistemska predstava o vlogi predšolske vzgoje je namreč pogosto povezana s pričakovanjem ekonomskega učinka $v$ prihodnosti, zato lahko vzgojnoizobraževalna praksa spregleda otroštvo tukaj in zdaj ter s tem razvojne potrebe otrok v času otroštva. Spregleda in zanika lahko tudi partikularne posebnosti, zmožnosti otrok in staršev, aspiracije in načine vsakdanjega življenja ter dejstvo, da je lahko določen socialno-ekonomski vidik (npr. starši brez prevoznega sredstva, slabe bivanjske razmere družine ...) ključna ovira pri 
dostopu do organizirane predšolske vzgoje. Otrokovi pogoji za razvoj in učenje so namreč odvisni od kompleksnega zdravstvenega in socialnega stanja družin, kar tudi vpliva na funkcionalnost družin. Na mnoge družinske situacije starši nimajo neposrednega vpliva (npr. neustrezno plačano delo staršev in zato nizki družinski dohodki, neustrezni delovni čas staršev, kar onemogoča stalno skrb za otroke, nedostopnost vrtcev).

Ob dejstvu, da zgodnje otroštvo pomeni občutljivo obdobje $z$ vidika razvoja otrokovih zmožnosti, je potrebno v procesu izobraževanja za poklic vzgojitelja poleg poznavanja kurikularnih področij ter načinov učenja in poučevanja otrok zagotoviti ustrezno senzibilizacijo strokovnih delavcev za prepoznavanje situacij vseh otrok (za njihovo socialno in zdravstveno stanje) ter funkcionalne zmožnosti družin. Raziskave sicer spodbudno kažejo, da imajo slovenske vzgojiteljice predšolskih otrok pozitivna stališča do inkluzije, ki so jih imele možnost razvijati na različnih stopnjah izobraževanja, vključno v času študija (Štemberger in Kiswarday 2017). To je pomembno spoznanje, saj S. Čotar Konrad (2018) izpostavlja, da bi moralo biti temeljno poslanstvo vzgojiteljice pri delu z družinami, da s svojim strokovnim delom (opazovanjem, pogovorom, odprtostjo, afiliativno naravnanostjo) in refleksijo lastnega poklicnega poslanstva opolnomoči funkcionalnost družine predšolskega otroka in posledično krepi otrokov psihosocialni razvoj. Obenem pa ugotavlja, da v slovenskem prostoru ni zagotovljenega sistematičnega usposabljanja vzgojiteljic za poznavanje in razumevanje specifičnih razvojnih nalog ter delovanja družine predšolskega otroka. Ob tem resno oviro pri opolnomočenju staršev oziroma družin predstavlja tudi neoliberalni diskurz navideznih neskončnih možnosti izbir in odločitev (Rose 1997), ki starše vodi v prevzemanje osebne odgovornosti za njihove načine življenja in življenjske pogoje. To se povezuje $z$ občutki porazov in neuspešnosti ob morebitni nezmožnosti zagotavljanja ustreznih materialnih pogojev ter medsebojnih odnosov v družinah. Starši (in morda tudi strokovni delavci v vrtcih) lahko spregledajo dejstvo, da je človekovo bivanje družbeno in socialno soodvisno, življenjske zmožnosti pa sistemsko pogojene (Bronfenbrenner 1994) s faktorji, ki vplivajo na dostop posameznika do materialnih in drugih bivanjskih pogojev. Zato starši pogosto nimajo drugih možnosti oziroma izbir.

Ob zagotavljanju ustreznih zdravstvenih pogojev in skrbi za zdravje otrokv vrtcih ter poznavanju družinskih in socialnih razmer otrok ter njihovih družin je treba upoštevati tudi otrokove predhodne spoznavne vsebine, priložnosti in navade, ki so kulturno kontekstualizirane. S tem je mogoče zagotoviti smiselnost (razvojno in kulturno odzivnost) ter učinkovitost vzgoje (rezultate). Izhajajoč iz študije, ki je preučevala ključne profesionalne kompetence vzgo- 
jiteljev (Urban idr. 2012), izhaja, da mora družba otrokom in družinam zagotoviti dostop do visokokakovostnih predšolskih programov in rezultatov, ki se kažejo v razvojnih in spoznavnih dosežkih otrok. Prav ti so namreč ključnega pomena za otroke, družine, skupnosti in širšo družbo. Kakovost, ki vodi do omenjenih rezultatov, pa mora vključevati vrednote in subjektivne predstave vseh, ki so vključeni v proces vzgoje, socialno konstrukcijo, refleksijo različnih kultur ter stalno usklajevanje vseh, vključenih v proces vzgoje (Dahlberg, Moss in Pence 2008).

\section{Zagotavljanje profesionalne, pedagoške in razvojne kontinuitete}

Lally idr. $(1996,17)$ so mnenja, da se razvojno primerni programi pomembno razlikujejo od programov za starejše otroke zaradi značilnosti in specifičnih potreb otrok do tretjega leta starosti, ki so povezane s spoznanji, da:

- se razvojne spremembe $v$ tem obdobju dogajajo veliko hitreje kot $v$ kateremkoli obdobju kasneje v življenju;

- so v času zgodnjega otroštva, tako kot v vseh drugih starostnih obdobjih, vsa razvojna področja - kognitivni, socialni, emocionalni in fizični razvoj - medsebojno prepletena;

- so otroci v zgodnjem otroštvu pri zadovoljevanju svojih potreb v celoti odvisni od odraslih;

- so majhni otroci v stiski še posebej ranljivi, ker se ne zmorejo aktivno spopadati z neugodjem ali s stresom.

Raziskave, še posebno s področja nevroznanosti, poudarjajo, da so otroci kompetentni učenci že od prenatalnega obdobja naprej (Dalli idr. 2011), zato je potrebno zagotoviti dostojanstveno in spoštljivo ravnanje z njimi (Goldschmied in Jackson 1994). Način ravnanja pa je utemeljen v vzorcih kulturnega in družbenega okolja ter interpretacijah otroka bodisi kot »bitja potreb« bodisi kot »bitja pravic«, kajti otroštvo je bilo in je sociokulturni konstrukt v vseh zgodovinskih obdobjih in družbenih okoljih (James in Prout 2003). Empirična spoznanja, ki jih povzema National Council on the Developing Child pri Harvard University, so pokazala, da je zdrav psihofizični razvoj otroka odvisen od kakovosti in zanesljivosti odnosov s pomembnimi drugimi (referenčnimi osebami v družini in izven nje) (National Scientific Council on the Developing Child 2004), kajti »zgodnje izkušnje so vgrajene v naša telesa« kot notranji model navezanosti, torej odnosa otroka do sebe in do okolja (Center on the Developing Child 2010, 1).

Ob zgoraj nevedenem je vsebinska profesionalizacija poklica vzgojitelja 
odvisna predvsem od predstave, podobe, razumevanja in razlage, kdo je otrok in kaj potrebuje za učenje ter razvoj v zgodnjem otroštvu. Bertram in Pascal (2016) opozarjata, da obstajajo velike razlike $v$ zakonskih podlagah, oblikah in vrstah predšolske vzgoje, dostopnosti in deležu otrok, vključenih $v$ predšolsko vzgojo, ter $v$ pričakovanjih na ravni različnih držav glede pričakovanih rezultatov, dosežkov otrok $v$ tem obdobju. Moss (2006) tudi ugotavlja, da neenovit, deljen sistem vzgoje predšolskih otrok vodi v deprofesionalizacijo, k različnim pričakovanjem ter normativom glede pričakovane in zahtevane stopnje izobrazbe strokovnih delavcev, ki delajo z otroki v njihovem prvem oziroma drugem starostnem obdobju. Podatki kažejo (Moss 2006), da so strokovni delavci v prvem starostnem obdobju v večini držav manj izobraženi, slabše plačani, večinoma gre za ženske.

Pedagoško kontinuiteto ( $z$ enovitim in celovitim kurikulumom) z namenom zagotavljanja ustreznega spodbujanja učenja in $s$ tem razvoja je zato mogoče zagotavljati izključno s profesionalno kontinuiteto - enako stopnjo in vrsto izobrazbe strokovnih delavcev, zaposlenih v ustanovah z otroki prvega in drugega starostnega obdobja, ter $s$ tem njihovo profesionalizacijo. Slednje pa je mogoče zagotoviti takrat, ko se strokovni delavci, ki delajo z otroki obeh starostnih obdobij, izobražujejo v izobraževalnih programih z enotnimi teoretičnimi, političnimi in etičnimi izhodišči - vrednotami, stališči in ravnanji.

Na sliki 1 predstavljamo sistemski model interakcij za vzpostavljanje celovite (skrb, varstvo, vzgoja in izobraževanje) in enovite (vzgoja in izobraževanje otrok prvega in drugega starostnega obdobja) predšolske vzgoje za potrebe integrirane (zdravstvo, sociala, izobraževanje) vzgoje otrok v vrtcih, ki tradicionalno, implicitno že obstaja. Povezuje državno in lokalno raven vrtca. Skozi diskurz integracije različnih vsebinskih področij (vzgoje in izobraževanja, socialnega in zdravstvenega področja) pa zagotavlja vzpostavljanje ustreznih strukturnih standardov kakovosti ter pedagoško in razvojno kontinuiteto.

Ugotavljamo, da je za zagotavljanje rezultatov v predšolski vzgoji treba zagotoviti integracijo ter povezanost zdravstvene, socialne in izobraževalne dimenzije, kar mora odsevati tudi vsebina strukturnih standardov kakovosti in procesnih načel kakovosti. Ravno slednja, procesna načela kakovosti, v slovenskem prostoru niso definirana.

Urban idr. (2012) poudarjajo, da mora kakovost vključevati vse spodaj navedene dimenzije:

- izkušnje in rezultate otrok (pripadanje, vključenost, psihološko blagostanje, oblikovanje smisla in pomena ter dosežke); 


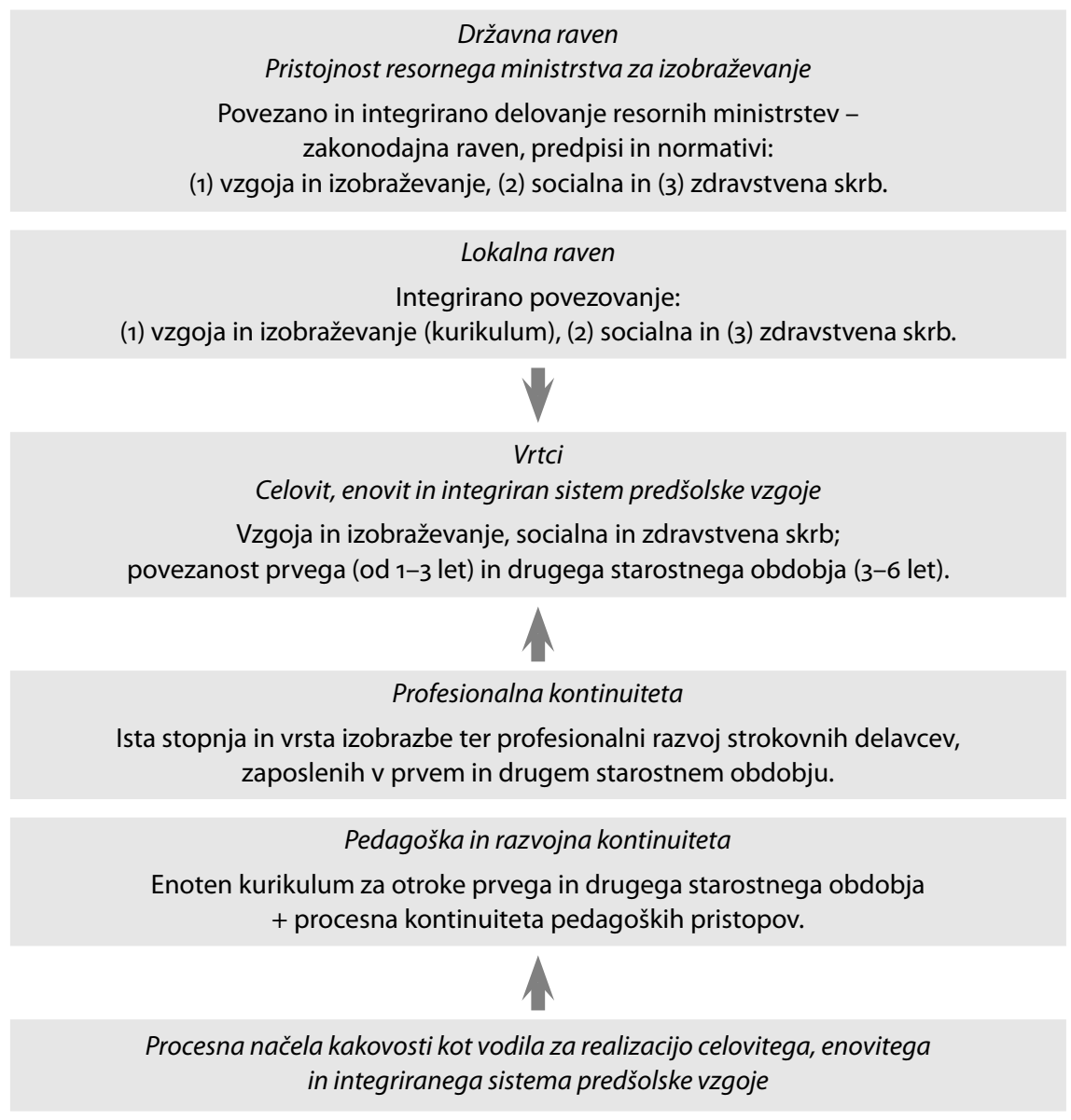

Slika 1 Organizacijski model celovitega, enovitega in integriranega sistema predšolske vzgoje

- izkušnje staršev in skrbnikov (pripadanje, vključenost, psihološko blagostanje, zagotavljanje dostopa do vrtcev);

- interakcije (med odraslimi in otroki, med otroki, med strokovnimi delavci in starši, med člani timov, med inštitucijami, med vrtcem in lokalno skupnostjo, med različnimi strokovnimi področji, med prakso in raziskovanjem, v okolju, kjer se izvaja pripravništvo, in na ravni vlade);

- strukturne pogoje (ustrezno razmerje med številom otrok in odraslih, ustrezno število otrok v skupini, velikost notranjih in zunanjih površin ter materialov za igro, plačane ure posrednega dela za otroke, zagotavljanje stalnega profesionalnega razvoja s podporo strokovnim delavcem pri raziskovanju lastne prakse in kritični refleksiji prakse); 
- sistem evalvacije, spremljanja in izboljševanja prakse (notranja in zunanja evalvacija z vključevanjem vseh deležnikov, na pobudo in s podporo izvajalcev predšolske vzgoje, ustanoviteljev oziroma lokalnih ali nacionalnih služb).

Kot primer ustreznih procesnih načel kakovosti navajamo vodila za profesionalno refleksijo, spremljanje in načrtovanje sprememb pedagoškega procesa v prvem starostnem obdobju, A Quality Framework for Early Childhood Practice in Services for Children under Three Years of Age (International Step by Step Association 2016). Ta vključujejo ravnanja, ki naj bi bila značilna za delo strokovnih delavcev $v$ pedagoškem procesu in so: (1) skrb za odnose, (2) spoštovanje družin in sodelovanje z njimi, vključevanje skupnosti, cenjenje raznolikosti in življenje vrednot demokracije; (3) skrb za zdravje, psihološko blagostanje in prehrano otrok; (4) skrb za spodbujanje celovitega razvoja in učenja otrok; (5) opazovanje, spremljanje razvoja, interesov, močnih strani in potreb otrok, dokumentiranje, refleksija in načrtovanje učenja; (6) zagotavljanje spodbudnega učnega okolja, ki otroku nudi varnost, psihološko blagostanje in priložnosti za učenje; (7) stalen profesionalni razvoj strokovnih delavcev; (8) medsektorsko povezovanje in sodelovanje z drugimi strokovnjaki, službami znotraj vrtca in med sektorji na način, ki zagotavlja zasebnost, zaupnost in dostojanstvo otrok ter družin. Verjamemo, da samo medresorska povezanost na državni in lokalni ravni, ki zagotavlja pogoje za integriran sistem delovanja na ravni vrtca, strokovnim delavcem omogoča senzibilizirano vzpostavljanje zdravstvene, socialne, vzgojne in izobraževalne skrbi ter odnosov z otroki, utemeljenih v procesnih vodilih zagotavljanja razvojne kontinuitete in prakse.

\section{Sklep}

Slovenija ima tradicionalo organiziran celovit in enovit sistem predšolske vzgoje, ki omogoča zagotavljanje profesionalne, pedagoške in razvojne kontinuitete. V prispevku nas je zanimalo, kako zagotoviti, da bodo vrtci ohranili senzibilnost in integriran pristop do otrok in njihovih družin, z vključevanjem vzgojno-izobraževalne, socialne in zdravstvene dimenzije.

S profesionalno kontinuiteto (za zaposlitev na delovnem mestu vzgojitelja $v$ prvem in drugem starostnem obdobju se zahtevata enaka stopnja in vrsta zaključenega programa) je zagotovljena oziroma omogočena razvojna kontinuiteta $v$ pedagoških pristopih in ravnanjih $v$ oddelkih prvega in drugega starostnega obdobja. Pomembno izhodišče integriranega delovanja je tudi enoten program, $z$ enakimi področji dejavnosti v kurikulumu za otroke pr- 
vega in drugega starostnega obdobja. S tem je zagotovljena pedagoška kontinuiteta. Enotna organizacijska in programska izhodišča so bila v Sloveniji vzpostavljena že z Vzgojnim programom za vzgojo in varstvo predšolskih otrok, izdanem leta 1979. Prenova izobraževanja leta 1996 in Kurikulum za vrtce (Ministrstvo za šolstvo in šport 1999) sta nadaljevala s to strokovno tradicijo.

Predvsem za otroke in družine otrok prvega starostnega obdobja je treba poleg razvojno primerne vzgoje in izobraževanja (z zagotavljanjem profesionalne in pedagoške kontinuitete) omogočiti tudi integriran sistem zdravstvene, socialne in kulturne senzibilnosti, ki smo ga predstavili v Organizacijskem modelu celovitega, enovitega in integriranega sistema predšolske vzgoje. Ta zagotavlja sinhronizirano povezanost strukturnih standardov in procesnih načel kakovosti.

V prispevku smo želeli izpostaviti potrebo po načrtno reflektirani sistemski strukturi organizacije predšolske vzgoje, ki v oddelku, na mikroravni, neposredno vpliva na vsebino in obliko vzgojno-izobraževalnih interakcij strokovnih delavcev z otroki. Verjamemo pa, da je ustrezna procesna načela kakovosti in pedagoška ravnanja $v$ prvem starostnem obdobju mogoče definirati ter realizirati izključno $s$ teoretično konceptualizacijo povezanosti vzgojnoizobraževalne, socialne in zdravstvene dimenzije.

In nenazadnje smo želeli opozoriti tudi na nevarnost prezrtosti razvojnih, socialnih, zdravstvenih, kulturnih raznolikosti, posebnosti in potreb otrok ter njihovih družin. Izhajamo iz prepričanja, da ranljivost staršev in otrok v zgodnjem obdobju še ne pomeni nekompetentnosti ali nezmožnosti. Zagotovo pa so za to obdobje značilni večja potreba po pomoči, navajanje staršev na novo vlogo, če gre za otroka prvorojenca, večja zdravstvena in socialna ranljivost, zato tudi večja potreba po zdravstveno in socialno senzibilnih/senzibiliziranih strokovnih delavcih, zaposlenih v vrtcih.

\section{Literatura}

Bertram, T., in C. Pascal. 2016. Early Childhood Policies and Systems in Eight Countries. Hamburg: International Association for the Evaluation of Educational Achievement.

Bronfenbrenner, U. 1994. »Ecological Models of Human Development.« V International Encyclopedia of Education, 3:1643-1647. 2. izd. Oxford: Elsevier.

Burger, K. 2010. »How Does Early Childhood Care and Education Affect Cognitive Development? An International Review of the Effects of Early Interventions for Children from Different Social Backgrounds. "Early Childhood Research Quarterly 25 (2): 140-165.

Center on the Developing Child. 2010. The Foundations of Lifelong Health Are Built in Early Childhood. Cambridge, MA: Harvard University. 
Čačinovič, G. 2008. Programske smernice: svetovalna služba v vrtcu. Ljubljana: Zavod Republike Slovenije za šolstvo.

Čotar Konrad, S. 2018. »Vloga vzgojiteljice pri opolnomočenju funkcionalnosti družine predšolskega otroka.«Pedagoška obzorja: časopis za didaktiko in metodiko 33 (1): 70-81.

Dahlberg, G., P. Moss in A. Pence. 2008. Beyond Quality in Early Childhood Education and Care: Languages of Evaluation. London in New York: Taylor \& Francis.

Dalli, C., E. J. White, J. Rockel, I. Duhn, E. Buchanan, S. Davidson, S. Ganly, L. Kus in B. Wang. 2011. Quality Early Childhood Education for Under-Two-YearOlds: What Should it Look Like? A Literature Review. Wellington: Ministry of Education.

Eurydice. 2019. Key Data on Early Childhood Education and Care in Europe: 2019 Edition; Eurydice Report. Luxembourg: Publications Office of the European Union.

Eurydice in Eurostat. 2014. Key Data on Early Childhood Education and Care in Europe: 2014 Edition; Eurydice and Eurostat Report. Luxembourg: Publications Office of the European Union.

Goldschmeid, E., in S. Jackson, S. 1994. People Under Three: Young Children in Day Care. London: Routledge.

Hart, B., in T. R. Risley. 1995. Meaningful Differences in the Everyday Experience of Young American Children. Baltimore, MD: Brookes.

International Step by Step Association. 2016. A Quality Framework for Early Childhood Practice in Services for Children under Three Years of Age. B. k.: International Step by Step Association.

James, A., in A. Prout. 2003. Constructing and Reconstructing Childhood:Contemporary Issues in the Sociological Study of Childhood. London: Routledge.

Kaga, Y., J. Bennett in P. Moss. 2010. Caring and Learning Together: A CrossNational Study on the Integration of Early Childhood Care and Education Within Education. Paris: Unesco.

Lally, R. J., S. Provence, E. Szanton in B. Weissbourd. 1996. »Developmentally Appropriate Care for Children From Birth to Age 3."V Developmentally Appropriate Practice in early Childhood Programs Serving Children From Birth Through Age 8, ur. S. Bredekamp, 17-33. Washington, DC: National Association for the Education of Young Children.

Lepičnik Vodopivec, J., in M. Hmelak. 2018. Vzgojitelji predšolskih otrok in skrb za lastni profesionalni razvoj. Koper: Založba Univerze na Primorskem.

Malaguzzi, L. 1994. "Your Image of the Child: Where Teaching Begins.» https://www.reggioalliance.org/downloads/malaguzzi:ccie:1994.pdf

Marjanovič Umek, L., U. Fekonja Peklaj, A. Hočevar in J. Lepičnik Vodopivec. 2011. Vrtci. V Bela knjiga o vzgoji in izobraževanju v Republiki Sloveniji, ur. J. Krek in M. Metljak, 63-105. Ljubljana: Pedagoški inštitut. 
Ministrstvo za šolstvo in šport. 1999. Kurikulum za vrtce: predšolska vzgoja v vrtcih. Ljubljana: Ministrstvo za šolstvo in šport.

Moss, P. 2006. "Structures, Understandings and Discourses: Possibilities for Re-Envisioning the Early Childhood Worker.« Contemporary Issues in Early Childhood 7 (1): 30-41.

Moss, P., in J. Bennett. 2006. »Toward a New Pedagogical Meeting Place? Bringing Early Childhood into the Education System."Predstavljeno na Nuffield Educational Seminar, London, 26 september. https://www .childcarecanada.org/sites/default/files/Bennett\%20and\%20Moss \%20(2006)\%20Towards\%20a\%2opedagogical\%2omeeting\%2oplace.pdf

National Scientific Council on the Developing Child. 2004. "Young Children Develop in an Environment of Relationships. " Working Paper 1, Harvard University, Cambridge, MA.

OECD. 2001. Starting Strong. Pariz: OECD. 2006. Starting Strong 2. Pariz: OECD.

Pavlič, S. 2006. Zgodovina idrijskega šolstva do leta 1945. Idrija: Bogataj.

Phillips, D. A., in J. P. Shonkoff, ur. 2000. From Neurons to Neighborhoods: The Science of Early Childhood Development. Washington, DC: National Academies Press.

Pravilnik o sprejemu otrok v vrtec. 2012. Uradni list Republike Slovenije, št. 28.

Rose, N. 1997. »Avtoriteta in genealogija subjektivnosti.« Časopis za kritiko znanosti 25 (183): 131-159.

Rossin-Slater, M. 2015. »Promoting Health in Early Childhood." The Future of Children 25 (1): 35-64.

Šebart Kovač, M., in M. Štefanc. 2017. »|zobraževanje otrok.« V Položaj otrok v Sloveniji danes: situacijska analiza, ur. A. Črnak Meglič in B. Kobal Tomc, 113139. Ljubljana: Inštitut Republike Slovenije za socialno varstvo.

Štemberger, T., in V. R. Kiswarday. 2018. »Attitude Towards Inclusive Education: The Perspective of Slovenian Preschool and Primary School Teachers. «European Journal of Special Needs Education 33 (1): 47-58.

Urban, M., M. Vandenbroeck, K. Van Laere, A. Lazzari in J. Peeters. 2012. »Towards Competent Systems in Early Childhood Education and Care: Implications for Policy and Practice.« European Journal of Education 47 (4): 508-526.

Vandenbroeck, M. 2011. »Diversity in Early Childhood Services." http://www .child-encyclopedia.com/sites/default/files/textes-experts/en/857/diversity -in-early-childhood-services.pdf

Vzgojni program za vzgojo in varstvo predšolskih otrok. 1979. Ljubljana: Zavod Socialistične Republike Slovenije za šolstvo.

Woodhead, M., S. Grantham-McGregor in S. Klaus. 2015. On Early Childhood Development. https://www.youtube.com/watch?v=1u97nDR3K3s

Zakon o vrtcih. 2005. Uradni list Republike Slovenije, št. 100.

Žlebnik, L. 1978. Obča zgodovina pedagogike. Ljubljana: DZS. 
A Comprehensive and Unitary System of Early Childhood Education and Care with the Integration of Educational, Health and Social Dimensions

The system and organization of early childhood education and care in Slovenia is unitary; ensures the connection of care, upbringing and education in the first and second age period. Developmental, pedagogical and professional continuity is ensured between the first and second age groups. The current form of system and continuity was already provided by the Educational program for education and care of preschool children (Vzgojni program za vzgojo in varstvo predšolskih otrok 1979) and later with the Kindergarten Curriculum (Kurikulum za vrtce 1999). The problem addressed in this paper is how to ensure sensibility and holistic approach to children and their families, including educational, social and health dimension, given the fact that child's development potentials, developmental and learning abilities and the health of children are directly related to the socio-economic conditions of children and their families.

Keywords: ICT, distance education, correspondence education, e-learning, higher education 